\title{
Variation of allozyme loci in populations of Drosophila melanogaster from the former USSR
}

\author{
OLEG A. BUBLI*, TATYANA A. RAKITSKAYA \& ALEXANDRA G. IMASHEVA \\ Vavilov Institute of General Genetics, Gubkin Street 3, 117809 GSP-1, Moscow B-333, Russia
}

\begin{abstract}
Variation of eight allozyme loci, $A c p h, A d h$, Est-6, Est-C, $\alpha$-Gpdh, Idh (NADP-dependent), 6-Pgd and Pgm, was studied in 20 populations of Drosophila melanogaster from the territory of the former USSR, including Eastern Europe, the Caucasus and Central Asia. Adh exhibited weak regression on latitude, longitude, and also on the temperature of the hottest calendar month in these localities. For seven other loci, no regular geographical pattern was found. Nei's coefficient of gene differentiation $\left(G_{\mathrm{ST}}\right)$ ranged from $0.010(6-P g d$, statistically nonsignificant) to $0.178(I d h)$ and was on average 0.058 . The average Nei's genetic distance $(D)$ between the populations was 0.011 . It is suggested that this fairly low level of interpopulation differentiation for the examined loci except $I d h$ may be explained by extensive gene flow in combination with natural selection.
\end{abstract}

Keywords: allozymes, Drosophila melanogaster, geographical variation, natural populations.

\section{Introduction}

In natural populations of Drosophila melanogaster, variation of some allozyme loci is well documented for North America, Australia, Western Europe and tropical Africa, East and South Asia (Oakeshott et al., 1981, 1982, 1983a,b and references therein; David, 1982; Triantaphyllidis et al., 1982; Watada et al., 1986; Singh \& Rhomberg, 1987a,b; Jiang et al., 1989; Parkash \& Shamina, 1994). The pattern of allele frequencies suggests that both selection and genetic drift operate in Drosophila populations. At the same time, specific mechanisms that determinate allozyme polymorphism remain obscure. Experimental evaluation of genotype fitness under laboratory conditions is one way towards resolving this problem. Another approach is to elucidate the complete pattern of allozyme differentiation over the world. Combination of these approaches can provide deeper understanding of evolutionary changes at the biochemical level.

In the present work, we report the geographical variation of eight allozyme loci in $D$. melanogaster populations from the former USSR territory. So far, this region remains very poorly investigated with regard to $D$. melanogaster biochemical variation. The

\footnotetext{
*Correspondence.
}

only study dealing with this issue was that of Grossman et al. (1970), and it was limited to the alcohol dehydrogenase locus; data on other loci are lacking. We consider variation at the following loci: $A d h$ (alcohol dehydrogenase, EC 1.1.1.1), $\alpha$-Gpdh $(\alpha$-glycerophosphate dehydrogenase, EC 1.1.1.8), Est-6 (esterase-6, EC 3.1.1.1), Est-C (esterase-C, EC 3.1.1.1), 6-Pgd (6-phosphogluconic dehydrogenase, EC 1.1.1.43), Pgm (phosphoglucomutase, EC 5.4.2.2), Acph (acid phosphatase, EC 3.1.3.2), and Idh (NADP-dependent isocitrate dehydrogenase, EC 1.1.1.42). There is a large body of evidence (e.g. Oakeshott et al., 1981, 1982, 1983a; David et al., 1982; Singh \& Rhomberg, 1987b; Parkash \& Shamina, 1994) that the first six loci exhibit latitudinal differentiation in some transects, which allows us to look on them as the most probable targets for natural selection.

\section{Materials and methods}

Samples of $D$. melanogaster were collected at 20 localities of Eastern Europe, the Caucasus and Central Asia. (Fig. 1, Table 1). The altitude of all localities did not exceed $1000 \mathrm{~m}$ above sea level. To eliminate possible seasonal and sampling bias in allele frequencies (see, e.g. Franklin, 1981), we restricted the sampling period to the two hottest 
summer months (from mid-July to early September) when $D$. melanogaster is most abundant in the region surveyed. Collections were made in orchards and vineyards, at fruit-processing factories, and at town fruit markets. In the laboratory, the flies were maintained as separate isofemale lines at $25^{\circ} \mathrm{C}$.

Allozyme variability was assayed by starch gel electrophoresis using the discontinuous system of Poulik (1957). The staining methods were adapted from Harris \& Hopkinson (1976). Fifty males per population were sampled in the $F_{1}$ generation for the analysis. For most populations, more than 50 isofemale lines were initiated; in electrophoretic analysis each line was represented by one fly. In three populations (Astrakhan, Gergebil and Makhinjauri), there were fewer than 50 isofemale lines and the samples for electrophoresis were made from 25 lines ( 2 flies per line). Allele frequency estimates obtained after such sampling procedures are expected to have a minimum bias (Long, 1993).

Expected heterozygosity $\left(H_{\mathrm{E}}\right)$ was calculated for each population according to Nei (1978). Genetic diversity analysis $\left(H_{\mathrm{T}}, H_{\mathrm{S}}, D_{\mathrm{ST}}, G_{\mathrm{ST}}\right)$ was performed following the method of Nei \& Chesser (1983). Homogeneity of allele frequencies among 20 populations was assessed using the $\chi^{2}$ procedure of Workman \& Niswander (1970).

Unbiased genetic distances between all possible pairs of populations were computed following Nei (1978). UPGMA cluster analysis (Sneath \& Sokal, 1973) was performed on this distance matrix and a strict consensus tree was found for the set of tied trees according to Sokal \& Rohlf (1981; for review see also Rohlf, 1982).

Table 1 Collection sites and population variability estimates for 20 populations of Drosophila melanogaster (size of each sample is 50 individuals)

\begin{tabular}{|c|c|c|c|c|c|}
\hline \multirow[b]{2}{*}{ Population } & \multicolumn{2}{|c|}{$\begin{array}{l}\text { Geographical } \\
\text { co-ordinates }\end{array}$} & \multirow{2}{*}{$\begin{array}{c}\text { Mean } \\
\text { number } \\
\text { of alleles } \\
\text { per locus }\end{array}$} & \multirow{2}{*}{$\begin{array}{l}\text { Observed } \\
\text { proportion } \\
\text { of loci } \\
\text { polymorphic* }\end{array}$} & \multirow{2}{*}{$\begin{array}{c}\text { Mean } \\
\text { heterozygosity } \\
\text { expected } \dagger \\
\pm \text { SE }\end{array}$} \\
\hline & $\begin{array}{l}\text { Latitude } \\
{ }^{\circ} \mathrm{N}\end{array}$ & $\stackrel{\text { Longitude }}{{ }^{\circ} \mathrm{E}}$ & & & \\
\hline \multicolumn{6}{|l|}{ Eastern Europe } \\
\hline 1 Tartu & 58.4 & 26.7 & 1.5 & 0.38 & $0.126 \pm 0.066$ \\
\hline 2 Ramenskoe & 55.6 & 38.3 & 1.6 & 0.38 & $0.157 \pm 0.069$ \\
\hline 3 Rybnoe & 54.7 & 39.5 & 1.8 & 0.63 & $0.193 \pm 0.065$ \\
\hline 4 Pyany Rog & 52.9 & 33.6 & 1.6 & 0.50 & $0.138 \pm 0.059$ \\
\hline 5 Gomel & 52.4 & 31.0 & 1.8 & 0.50 & $0.202 \pm 0.079$ \\
\hline 6 Khristinovka & 48.8 & 30.0 & 1.8 & 0.63 & $0.167 \pm 0.064$ \\
\hline 7 Kishinev & 47.0 & 28.8 & 1.8 & 0.63 & $0.188 \pm 0.061$ \\
\hline 8 Zabuzan & 46.5 & 48.3 & 1.6 & 0.50 & $0.176 \pm 0.074$ \\
\hline 9 Astrakhan & 46.4 & 48.1 & 1.9 & 0.50 & $0.190 \pm 0.070$ \\
\hline 10 Vilino & 44.9 & 33.6 & 1.4 & 0.25 & $0.115 \pm 0.073$ \\
\hline \multicolumn{6}{|l|}{ Caucasus } \\
\hline 11 Jankhot & 44.4 & 38.2 & 1.6 & 0.38 & $0.136 \pm 0.070$ \\
\hline 12 Sochi & 43.6 & 39.7 & 1.8 & 0.50 & $0.182 \pm 0.071$ \\
\hline 13 Gergebil & 42.5 & 47.1 & 1.8 & 0.38 & $0.162 \pm 0.072$ \\
\hline 14 Makhinjauri & 41.7 & 41.7 & 1.8 & 0.38 & $0.164 \pm 0.073$ \\
\hline \multicolumn{6}{|l|}{ Central Asia } \\
\hline 15 Alma-Ata & 43.3 & 77.0 & 1.8 & 0.50 & $0.212 \pm 0.075$ \\
\hline 16 Akzhar & 43.1 & 71.6 & 1.6 & 0.38 & $0.169 \pm 0.079$ \\
\hline 17 Jambul & 42.9 & 71.4 & 1.8 & 0.75 & $0.244 \pm 0.073$ \\
\hline 18 Kaplanbek & 41.5 & 69.4 & 1.8 & 0.38 & $0.128 \pm 0.059$ \\
\hline 19 Cheptura & 38.5 & 68.4 & 1.8 & 0.63 & $0.239 \pm 0.077$ \\
\hline 20 Bezmein & 38.1 & 58.2 & 1.8 & 0.38 & $0.174 \pm 0.073$ \\
\hline \multirow{2}{*}{\multicolumn{3}{|c|}{$\begin{array}{l}\text { Average } \\
\text { SE }\end{array}$}} & 1.72 & 0.48 & 0.173 \\
\hline & & & 0.03 & 0.03 & 0.008 \\
\hline
\end{tabular}

${ }^{*}$ A locus is considered polymorphic if the frequency of the most common allele does not exceed 0.95 .

†Unbiased estimate according to Nei (1978). 


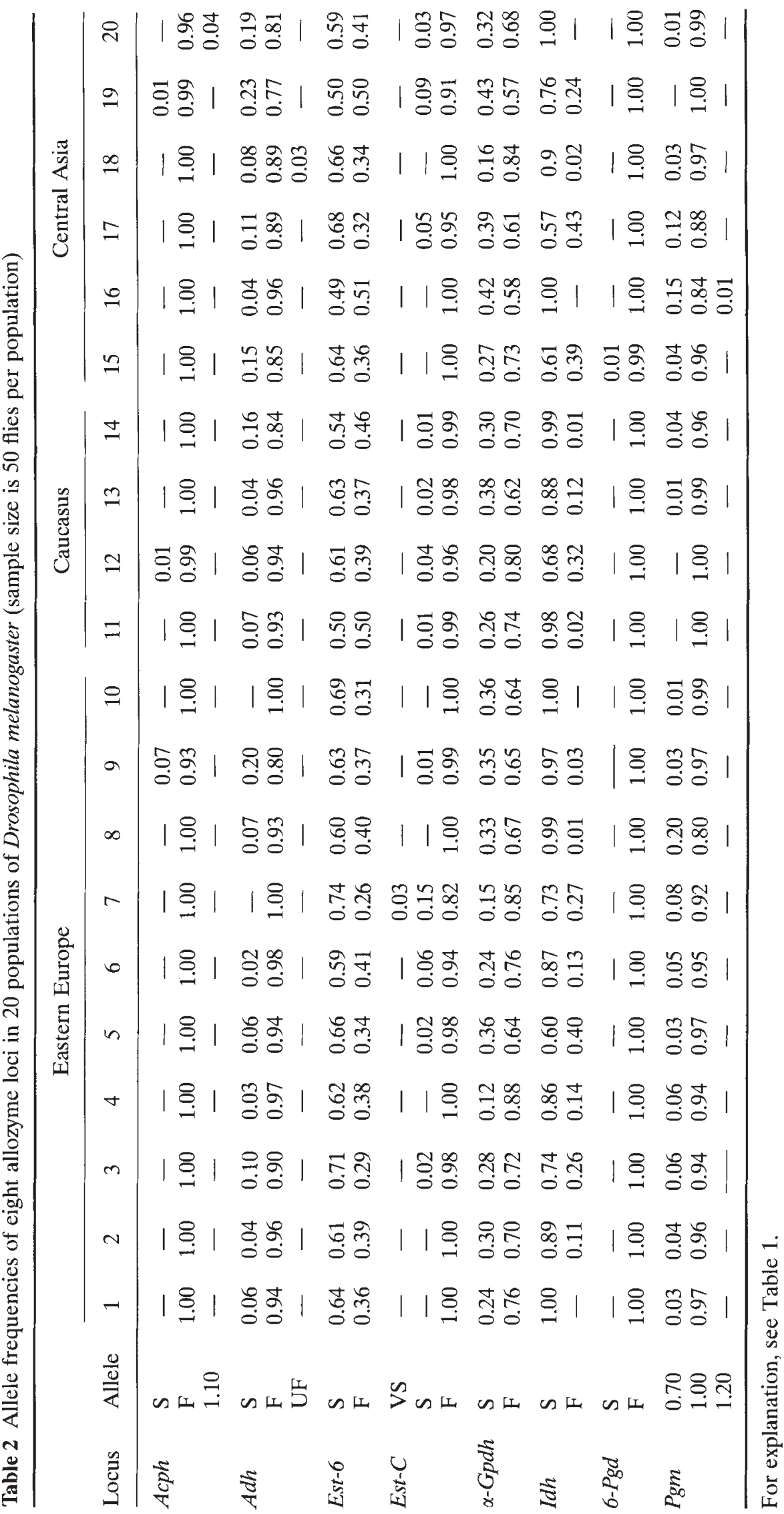


The qualitative estimates of the level of gene flow among populations were obtained with Slatkin's method based on private allele frequencies (Slatkin, 1985 ) and Crow's method based on $G_{\mathrm{ST}}$ of populations at equilibrium (Crow, 1986; for theoretical background see Wright, 1969). The Ewens-Watterson test of neutrality for the loci was performed following Manly (1985).

Statistical computations were performed using the BIOSYS-1 (Swofford \& Selander, 1989) and NTSYS-pc (Rohlf, 1988) computer programs.

\section{Results}

The variability estimates for 20 populations of $D$. melanogaster from Eastern Europe, the Caucasus and Central Asia are presented in Table 1. An average population was polymorphic for 48 per cent of its loci according to the 95 per cent criterion and had on average 1.72 alleles per locus. The average heterozygosity per locus was 0.173 . The mean number of alleles per locus was virtually constant from one population to another. The proportion of polymorphic loci and heterozygosity estimates were more variable but no obvious geographical trends were detected.

In Tables 2 and 3, the allele frequencies of the eight loci surveyed and their variability estimates over 20 populations are presented. All the loci were polymorphic according to the 99 per cent criterion and seven loci were polymorphic according to the 95 per cent criterion (the exception was 6-Pgd). The mean number of alleles per population ranged from
$1.05(6-P g d)$ to $2.00($ Est-6, $\alpha-G p d h)$ and was, on average, 1.63. For six loci, most populations had two alleles. One allele predominated in the populations for $A c p h$ and $6-P g d$. There were only three cases in which three alleles of one locus were present in a population simultaneously (see Table 2).

Only the $A d h$ locus exhibited a statistically significant relationship with the geographical position of populations and temperature of the hottest calendar month (July). Regression coefficients of the Adh-F allele frequency on latitude, longitude and temperature were $5.69 \times 10^{-3} \quad(P<0.05), \quad-2.35 \times 10^{-3}$ $(P<0.01)$ and $-11.57 \times 10^{-3}(P<0.01)$, respectively.

Gene diversity analysis indicated that only 5.81 per cent of the total genetic variation resided among populations (Table 3). However, seven of the eight loci (exception 6-Pgd) were found to be heterogeneous among populations according to the Workman-Niswander $\chi^{2}$ test, with Idh displaying considerable interpopulation differentiation.

Nei's genetic distance estimates were fairly low amounting on average to $0.011 \pm 0.001$. The regression of genetic distance on geographical distance was very slight (regression coefficient of $6.45 \times 10^{-7}$, $P<0.05$ ) and accounted for only 2.74 per cent of the total genetic distance variation. It is not surprising then that cluster analysis could not reveal clear geographical population groups (Fig. 2). As no single solution in the construction of the dendrogram was available, we represented on Fig. 2 a strict consensus tree with a $C I_{\mathrm{C}}$ consensus index of 0.39 .

Both Slatkin's and Crow's methods gave high estimates of gene flow among the populations studied.

Table 3 Variation of eight allozyme loci over 20 populations of Drosophila melanogaster

\begin{tabular}{|c|c|c|c|c|c|c|c|}
\hline \multirow[b]{2}{*}{ Locus } & \multirow{2}{*}{$\begin{array}{l}\text { Proportion of } \\
\text { populations } \\
\text { polymorphic } \dagger\end{array}$} & \multirow{2}{*}{$\begin{array}{l}\text { Mean number of } \\
\text { alleles per } \\
\text { population }\end{array}$} & \multicolumn{4}{|c|}{ Gene diversity statistics $\ddagger$} & \multirow{2}{*}{$\begin{array}{c}\text { Heterogeneity } \\
\text { test } \$, \\
\chi^{2}\end{array}$} \\
\hline & & & $H_{\Upsilon}$ & $H_{\mathrm{S}}$ & $D_{\mathrm{ST}}$ & $G_{\mathrm{ST}}$ & \\
\hline Acph & 0.05 & 1.20 & 0.014 & 0.013 & 0.001 & 0.047 & $* * *$ \\
\hline$A d h$ & 0.65 & 1.95 & 0.161 & 0.152 & 0.009 & 0.055 & $* * *$ \\
\hline Est-6 & 1.00 & 2.00 & 0.478 & 0.468 & 0.009 & 0.019 & $* *$ \\
\hline Est-C & 0.20 & 1.65 & 0.053 & 0.050 & 0.003 & 0.061 & $* * *$ \\
\hline$\alpha-G p d h$ & 1.00 & 2.00 & 0.418 & 0.403 & 0.015 & 0.036 & $* * *$ \\
\hline$I d h$ & 0.55 & 1.80 & 0.251 & 0.206 & 0.045 & 0.178 & $* * *$ \\
\hline 6-Pgd & 0.00 & 1.05 & 0.001 & 0.001 & 0.000 & 0.010 & $\mathrm{~ns}$ \\
\hline Pgm & 0.35 & 1.90 & 0.098 & 0.092 & 0.006 & 0.059 & $* * *$ \\
\hline Average & 0.48 & 1.69 & 0.184 & 0.173 & 0.011 & 0.058 & $* * *$ \\
\hline $\mathrm{SE}$ & 0.14 & 0.13 & 0.065 & 0.062 & 0.005 & 0.018 & - \\
\hline
\end{tabular}

$\uparrow$ A population is considered polymorphic if the frequency of the most common allele does not exceed 0.95 .

$\ddagger$ According to Nei \& Chesser (1983).

§According to Workman \& Niswander (1970).

${ }^{* *} P<0.01, * * * P<0.001 ; \mathrm{NS}$, nonsignificant.

(C) The Genetical Society of Great Britain, Heredity, 77, 638-645. 


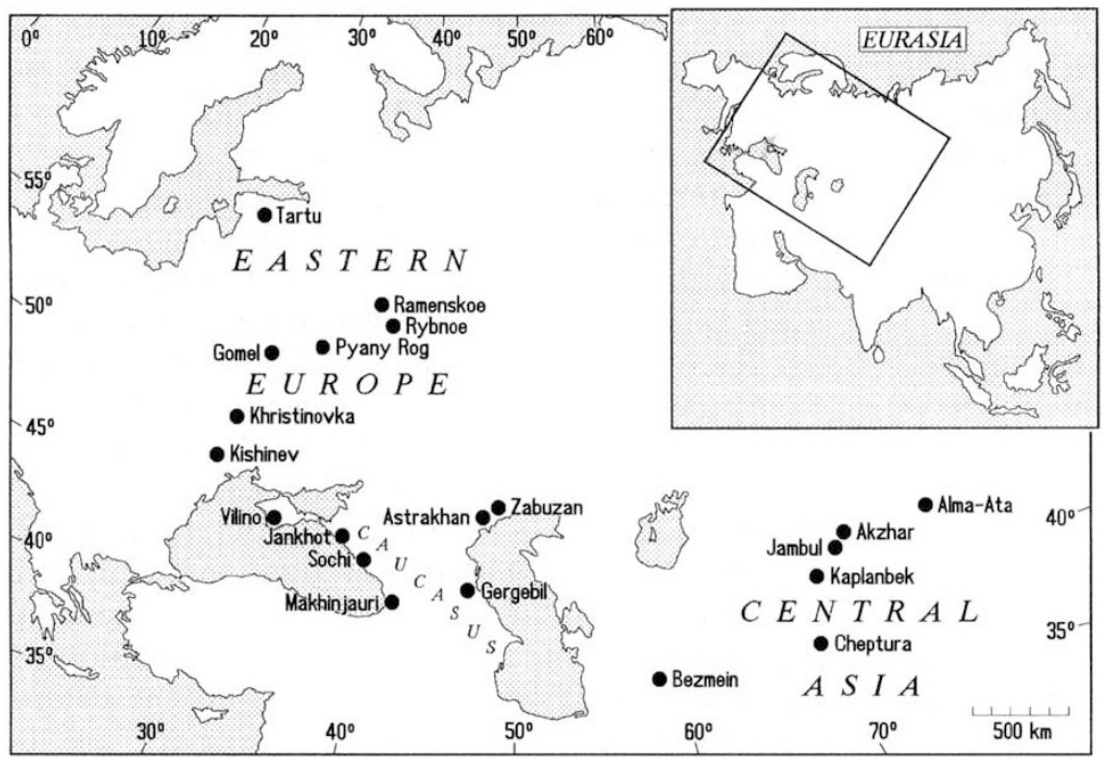

Fig. 1 Geographical locations of the 20 sampled populations of Drosophila melanogaster.
The average frequency of the private alleles (alleles that were found in only one population), $p(1)$ was $0.024 \pm 0.006$ and according to Slatkin's method $\mathrm{Nm}$ (the average number of migrants exchanged between populations) was 6.43 . $\mathrm{Nm}$ calculated according to Crow's method using the average $G_{\mathrm{ST}}$ was 3.66 .

Table 4 represents the results of the EwensWatterson test of neutrality for seven loci that exhibited statistically significant among-population heterogeneity (see Table 3 ). Because the migration rate was found to be quite high, we considered the situation when the samples were treated as belonging to one population. Except Acph, all approximate percentage points for sample homozygosity were between 0.05 and 0.95 and thus the hypothesis of neutrality could not be rejected for these loci.

\section{Discussion}

In the present study, we deal with variation of allozyme loci most of which exhibit a considerable differentiation among the $D$. melanogaster populations throughout the world (Oakeshott et al., 1981, 1982, 1983a; David, 1982; Triantaphyllidis et al., 1982; Lamooza et al., 1985; Watada et al., 1986; Singh \& Rhomberg, 1987a,b; David et al., 1989; Jiang et al., 1989; Parkash \& Shamina, 1994). Though the populations that we surveyed were geographically distant and occupied both temperate and subtropical habitats, the range of allele frequencies and level of interpopulation differentiation were shown to be rather low.

There are two main factors which result in low

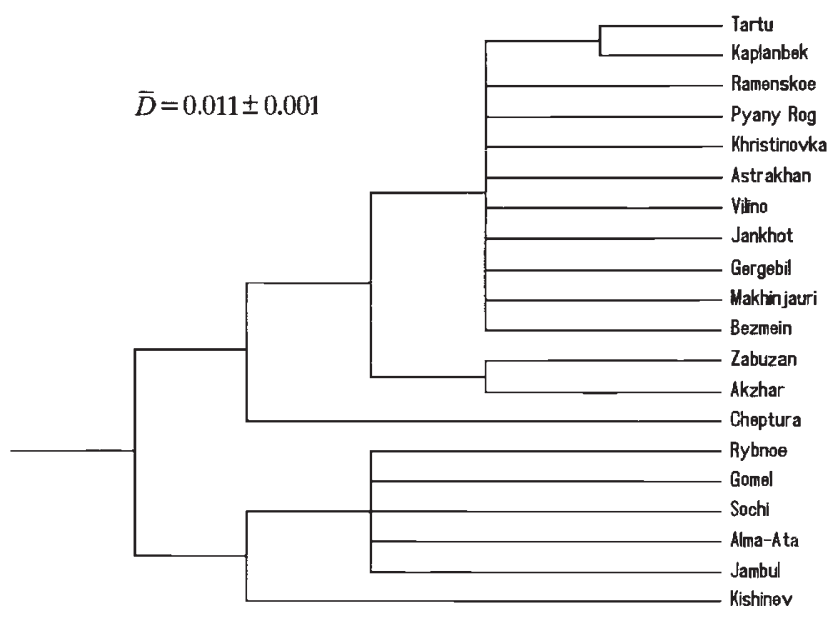

Fig. 2 UPGMA cluster analysis of Nei's genetic distances among 20 populations of Drosophila melanogaster: a strict consensus tree $\left(C I_{\mathrm{C}}=0.39\right)$ for the set of tied dendrograms.

variation of polymorphic loci over the range of a species. One is extensive gene flow which equalizes allele frequencies of neutral loci. Another factor is strong selection associated with some quite constant climatic parameter(s). There can also be some interaction of these factors.

The qualitative evaluation of gene flow among the populations of Eastern Europe, the Caucasus and Central Asia indicates that it is quite large $(\mathrm{Nm}>1)$. This is in good agreement with the results obtained previously for D. melanogaster (Coyne et al., 1982, 1987; Singh \& Rhomberg, 1987a; Hale \& Singh, 
Table 4 Ewens-Watterson test of neutrality with an assumption of high migration between the populations of Drosophila melanogaster*

\begin{tabular}{lccc}
\hline Locus $\dagger$ & $\begin{array}{c}\text { Allele } \\
\text { number, } k\end{array}$ & $\begin{array}{c}\text { Sample } \\
\text { homozygosity, } \hat{F}\end{array}$ & $\begin{array}{c}\text { Approx. corresp. } \\
\text { percentage points, } P\end{array}$ \\
\hline Acph & 3 & 0.987 & 0.95 \\
Adh & 3 & 0.841 & 0.55 \\
Est- 6 & 2 & 0.527 & 0.08 \\
Est-C & 3 & 0.947 & 0.78 \\
$\alpha-G p d h$ & 2 & 0.586 & 0.12 \\
$I d h$ & 2 & 0.752 & 0.25 \\
$P g m$ & 3 & 0.903 & 0.68 \\
\hline
\end{tabular}

*According to Manly (1985).

$\lceil 6-P g d$ was excluded from consideration because of its statistically nonsignificant differentiation among the populations.

1991) and appears to be reasonable for the region surveyed. Traditional extensive transportation of fruits and vegetables from the south to north, existing in this territory, can promote a high level of passive migration of $D$. melanogaster.

A comparison of the allele frequencies scored in the present study with data of other authors for Eurasian populations (see references in the first paragraph) indicates that selection can also maintain the low allozyme variation found in Eastern Europe, the Caucasus and Central Asia. The allele frequencies in this region resemble those obtained previously for temperate and subtropical Eurasian populations, with Acph, $\alpha-G p d h, E s t-C, 6-P g d$ and Pgm exhibiting low or very low interpopulation differentiation. At the same time, a parallel latitudinal variation between temperate/subtropical and tropical habitats in different continents was documented for Adh, $\alpha-G p d h, E s t-6$, Est-C, 6-Pgd and Pgm. Such a geographical pattern suggests some selection pressure on these loci. The most probable type of selection appears to be a balancing diversifying one, with coefficients corresponding to climatic gradients between high latitudes and the equator (see Singh \& Rhomberg, 1987b for discussion). At the Acph locus, one allele predominates in both tropical and temperate populations; this may result from strong purifying selection against rare alleles.

As to Idh, no data on geographical variation in other transects are available for this locus. In our study, it shows the highest and random interpopulation differentiation, i.e. it more closely resembles a neutral locus.

The results of the Ewens-Watterson test of neutrality may appear at first sight to conflict with the conclusions based on the worldwide pattern of geographical variation. According to the test, only the Acph locus is under selection. Of course, we should view this conclusion with some scepticism. Rigorous results can be obtained only for low homozygosity values, provided that there is an equilibrium distribution of allele numbers and all alleles are identified (for details see Manly, 1985). Not all these requirements can be met in our study. However, a consideration of the test results in relation to data on the loci variation over the world allows this situation to be regarded as quite realistic for the region studied.

The locus $A c p h$ is monomorphic or almost monomorphic in $D$. melanogaster populations all over the world. It has high sample homozygosity that according to the Ewens-Watterson test will give a statistically significant deviation from neutrality for any part of the species range. The loci $A d h, \alpha-G p d h$, Est-6, Est-C, 6-Pgd and Pgm exhibit considerable differentiation between temperate/subtropical and tropical habitats. However, these loci normally show low or moderate variation within temperate/subtropical climates. Their sample homozygosity values are intermediate there; consequently, they cannot give statistically significant deviation from neutrality. If we combine temperate/subtropical populations with tropical ones, which have another ratio for the main allele frequencies, we might obtain a decrease in sample homozygosity. In this case, the EwensWatterson test is likely to provide evidence for balancing selection rather then neutrality.

It is usually suggested that the most apparent selective agent to maintain the geographical variation between temperate/subtropical and tropical habitats is temperature in Drosophila breeding sites. Especially for $A d h$, there is a large body of data on 
this issue, derived from both field observations and laboratory experiments (for review, see e.g. Chambers, 1988). Even with the low interpopulation differentiation, shown in the present study, the $A d h$ allele frequencies exhibited a statistically significant regression on latitude and the temperature of the hottest month. Clinal geographical and altitudinal $A d h$ variation in this region has also been previously demonstrated by Grossman et al. (1970). For the loci $\alpha-G p d h$, Est-6, Est-C, 6-Pgd and Pgm, the temperature gradient along the transect was likely to be insufficient to result in such regular geographical variation. The pattern of their allele frequency distribution could be determined by interaction between gene flow and some specific factors within the limits of macroclimatic temperature-dependent selection.

Subtle mechanisms of selection are, however, uncertain. In vitro analysis of thermostabilities and kinetic properties of allozymes under different temperatures yielded results which were frequently in contrast with what could be expected from the existent geographical and seasonal variation (see e.g. Zera et al., 1984 and Chambers, 1988 for reviews; Oakeshott et al., 1983a and White et al., 1988 for discussions). Therefore, it was hypothesized that temperature had also various indirect effects on allozyme genotypes. For instance, selection might maintain the $A d h$ clines through a higher developmental rate of the $A d h-F F$ genotypes as a result of higher enzyme activity of ADH-F (Oudman et al., 1991). Rapid development ( $r$-strategy) is held to be an advantage in extreme climates far from the equator (Parsons, 1983).

Another possibility is hitch-hiking with cosmopolitan inversions. These inversions display clear latitudinal differentiation in $D$. melanogaster (see Lemeunier et al., 1986; Sperlich \& Pfriem, 1986 for reviews) which can reflect adaptation to environmental stress (Dobzhansky, 1970). In laboratory experiments, van Delden \& Kamping (1989) demonstrated that the $A d h-s$ and $\alpha-G p d h-F$ alleles may be hitch-hiking with $\operatorname{In}(2 \mathrm{~L})$ t. However, some authors (e.g. Voelker et al., 1978; Oakeshott et al., 1982; Singh \& Rhomberg, 1987b) argue that the inversions fail to account fully for the allozyme geographical variation in $D$. melanogaster. Obviously, more data are required for elucidation of selective mechanisms in natural populations.

\section{Acknowledgements}

We thank Prof. Wilke van Delden and Dr Boris Kalabushkin for comments on the manuscript. The work was supported by the Russian State Programmes 'Frontiers in Genetics' and 'Biodiversity'.

\section{References}

CHAmbers, G. K. 1988. The Drosophila alcohol dehydrogenase gene-enzyme system. Adv. Genet., 25, 39-107.

COYNE, J. A., BOUSSY, I. A., PROUT, T., BRYANT, S. H., JONES, J. S. AND MOORE, J. A. 1982. Long-distance migration of Drosophila. Am. Nat., 119, 589-595.

COYNE, J. A., BRYANT, S. H. AND TURELLI, M. 1987. Longdistance migration of Drosophila. 2. Presence in desolate sites and dispersal near a desert oasis. Am. Nat., 129, 847-861.

Crow, J. F. 1986. Basic Concepts in Population, Quantitative, and Evolutionary Genetics. W. H. Freeman, New York.

DAVID, J. R. 1982. Latitudinal variability of Drosophila melanogaster: Allozyme frequencies divergence between European and Afrotropical populations. Biochem. Genet., 20, 747-761.

DAVID, J. R., AlONSO-MORAGA, A., BORAI, F., CAPY, P., MERÇOT, H., McEVEY, S. F. ET AL. 1989. Latitudinal variation of $A d h$ gene frequencies in Drosophila melanogaster: a Mediterranean instability. Heredity, 62, 11-16.

DOBZHANSKY, TH. 1970. Genetics of the Evolutionary Process. Columbia University Press, New York.

FRANKLIN, J. R. 1981. An analysis of temporal variation at isozyme loci in Drosophila melanogaster. In: Gibson, J. B. \& Oakeshott, J. G. (eds) Genetic Studies of Drosophila Populations, pp. 217-236. Australian National University Press, Canberra.

GRossman, A. I., KORENEVA, L. G. AND ULITSKAYA, L. E. 1970. Variation of the alcohol dehydrogenase locus $(\mathrm{ADH})$ in natural populations of Drosophila melanogaster. Genetika (Moscow), 6, 91-96.

HALE, L. R. AND SINGH, R. S. 1991. A comprehensive study of genic variation in natural populations of Drosophila melanogaster. IV. Mitochondrial DNA variation and the role of history vs. selection in the genetic structure of geographic populations. Genetics, 129, 103-117.

HARRIS, H. AND HOPKINSON, D. A. 1976. Handbook of Enzyme Electrophoresis in Human Genetics. NorthHolland, Amsterdam.

JIANG, C., GIBSON, J. B. AND CHEN, H. 1989. Genetic differentiation in populations of Drosophila melanogaster from the Peoples' Republic of China: comparison with patterns on other continents. Heredity, 62, 193-198.

LAMOOZA, S. B., ALI, S. R. AND AL-TAWEEL, A. A. 1985. Enzyme polymorphism in Drosophila melanogaster populations in Iraq. Biochem. Genet., 23, 321-328.

LEMEUNIER, F., DAVID, J. R., TSACAS, L. AND ASHBURNER, M. 1986. The melanogaster species group. In: Ashburner, M., Carson, H. L. \& Thompson, J. N., Jr. (eds) The Genetics and Biology of Drosophila, vol. 3e, pp. 147-256. Academic Press, London.

LONG, A. D. 1993. A correction for allele frequency esti- 
mates derived from isofemale lines. Biochem. Genet., 31, 61-74.

MANLY, B. F. J. 1985. The Statistics of Natural Selection on Animal Populations. Chapman and Hall, London.

NEI, M. 1978. Estimation of average heterozygosity and genetic distance from a small number of individuals. Genetics, 89, 583-590.

NEI, M. AND CHESSER, R. K. 1983. Estimation of fixation indices and gene diversities. Ann. Hum. Genet., 47, 253-259.

OAKESHOTT, J. G., CHAMBERS, G. K., GIBSON, G. B. AND wILLCOCKS, D. A. 1981. Latitudinal relationships of esterase-6 and phosphoglucomutase gene frequencies in Drosophila melanogaster. Heredity, 47, 385-396.

OAKESHOTT, J. G., GIBSON, J. B., ANDERSON, P. R., KNIBB, W. R., ANDERSON, D. G. AND CHAMBERs, G. K. 1982. Alcohol dehydrogenase and glycerol-3-phosphate dehydrogenase clines in Drosophila melanogaster on different continents. Evolution, 36, 86-96.

OAKESHOTT, J. G., CHAMBERS, G. K., GIBSON, J. B., EANES, W. F. AND WILlCOCKS, D. A. 1983a. Geographic variation in G6pd and Pgd allele frequencies in Drosophila melanogaster. Heredity, 50, 67-72.

OAKESHOTT, J. G., GIBSON, J. B., WILLCOCKS, D. A. AND CHAMBERS, G. K. 1983b. Latitudinal variation in octanol dehydrogenase and acid phosphatase allele frequencies in Drosophila melanogaster. Theor. Appl. Genet., 65, 191-196.

OUDMAN, L., VAN DELDEN, W., KAMPING, A. AND BIJLSMA, R. 1991. Polymorphism at the $A d h$ and $\alpha G p d h$ loci in Drosophila melanogaster: effects of rearing temperature on developmental rate, body weight, and some biochemical parameters. Heredity, 67, 103-115.

PARKASH, R. AND SHAMINA. 1994. Geographical differentiation of allozymic variability in natural Indian populations of Drosophila melanogaster. Biochem. Genet., 32, 63-73.

PARSONS, P. A. 1983. The Evolutionary Biology of Colonizing Species. Cambridge University Press, New York.

POULIK, M. D. 1957. Starch gel electrophoresis in a discontinuous system of buffers. Nature, 180, 1477-1479.

ROHLF, F. J. 1982. Consensus indices for comparing classifications. Math. Biosci., 59, 131-144.

ROHLF, F. J. 1988. NTSYS-pc. Numerical taxonomy and multivariate analysis system. Exeter, Setauket, NY.

SINGH, R. S. AND RHOMBERG, L. R. 1987a. A comprehensive study of genic variation in natural populations of Drosophila melanogaster. I. Estimates of gene flow from rare alleles. Genetics, 115, 313-322.

SINGH, R. S. AND RHOMBERG, L. R. 1987b. A comprehensive study of genetic variation in natural populations of Drosophila melanogaster. II. Estimates of heterozygosity and patterns of geographic differentiation. Genetics, 117, $255-271$.

SLATKIN, M. 1985. Rare alleles as indicators of gene flow. Evolution, 39, 53-65.

SNEATH, P. AND SOKAL, R. R. 1973. Numerical Taxonomy.

W. H. Freeman, San Francisco, CA.

SOKAL, R. R. AND ROHLF, F. J. 1981. Taxonomic congruence in the Leptopodomorpha re-examined. Syst. Zool., 30, 309-325.

SPERLICH, D. AND PFRIEM, P. 1986. Chromosomal polymorphism in natural and experimental populations. In: Ashburner, M., Carson, H. L. \& Thompson, J. N., Jr. (eds) The Genetics and Biology of Drosophila, vol. 3e, pp. 257-309. Academic Press, London,

SWOFFORD, D. L. AND SELANDER, R. B. 1989. BIOSYS-1. $A$ Computer Program for the Analysis of Allelic Variation in Population Genetics and Biochemical Systematics. Release 1.7. University of Illinois, Urbana, IL.

TRIANTAPHYLLIDIS, C. D., SCOURAS, Z. G., PANOURGIAS, J. N. AND IOANNIDIS, G. C. 1982. Allozyme variation in Greek wild populations of Drosophila melanogaster and $D$. simulans along a North-South gradient. Genetica, 58, 129-136.

VAN DELDEN, w. AND KAMPING, A. 1989. The association between the polymorphisms at the $A d h$ and $\alpha-G p d h$ loci and the $\operatorname{In}(2 \mathrm{~L}) \mathrm{t}$ inversion in Drosophila melanogaster in relation to temperature. Evolution, 43, 775-793.

VOELKER, R. A., COCKERHAM, C. C., JOHNSON, F. M., SCHAFFER, H. E., MUKAI, T. AND METTLER, L. E. 1978. Inversions fail to account for allozyme clines. Genetics, $88,515-527$.

WATADA, M., TOBARI, Y. N. AND OHBA, s. 1986. Genetic differentiation in Japanese populations of Drosophila simulans and D. melanogaster. I. Allozyme polymorphisms. Jap. J. Genet., 61, 253-269.

WHITE, M. M., MANE, S. D. AND RICHMOND, R. C. 1988. Studies of esterase-6 in Drosophila melanogaster. XVIII. Biochemical differences between the Slow and Fast allozymes. Mol. Biol. Evol, , 5, 41-62.

WORKMAN, P. L. AND NISWANDER, J. D. 1970. Population studies on southwestern Indian tribes. II. Local genetic differentiation in the Papago. Am. J. Hum. Genet., 22, 24-49.

WRIGHT, s. 1969. Evolution and Genetics of Populations, vol. 2, The Theory of Gene Frequencies. University of Chicago Press, Chicago, IL.

ZERA, A. J., KOEHN, R. K. AND HALL, J. G. 1984. Allozymes and biochemical adaptation. In: Kerkut, A. \& Gilbert, L. I. (eds) Comprehensive Insect Physiology, Biochemistry, and Pharmacology, vol. 10, pp. 81-112. Pergamon Press, New York. 